\title{
PENGARUH KONSENTRASI EKSTRAK BUAH PEDADA (Sonneratia caseolaris) TERHADAP MUTU TAHU PADA PENYIMPANAN SUHU RUANG
}

\author{
Effect Of Concentration Of Pedada Fruit (Sonneratia Caseolaris) Extract To Tofu \\ Quality During Room Temperature Storage
}

\author{
Nenengsih Verawati ${ }^{1)}$, Isye Selvianti ${ }^{1)}$, dan Syf. Umi Kalsum ${ }^{2)}$ \\ ${ }^{1)}$ Program Studi Teknologi Pengolahan Hasil Perkebunan, Politeknik Negeri Ketapang \\ ${ }^{2)}$ Jurusan Pertambangan, Politeknik Negeri Ketapang \\ email: nenengerman_1@yahoo.com
}

\begin{abstract}
Pedada fruit is one type of mangrove plant that has strong antibacterial properties that has not been used for food preservation. Tofu is easily spoilage food so it needs to be preserved to extend its shelf life. The purpose of this study is to know the effect of pedada fruit extract concentration on clear zone, total plate count, $\mathrm{pH}$, moisture content in room temperature storage, and to know appropriate concentration of pedada fruit extract in inhibiting the growth of tested bacteria: Escherichia coli and Staphilococcus aureus on tofu during room temperature storage. Study of antibacterial effectiveness is conducted on those tested bacteria with concentration 4\%, 6\% and 8\% of pedada fruit extract, then analysis of tofu quality is carried out by soaking tofu in pedada fruit extract during day 0, 1, 2 and 3 of storage. The study is conducted using a randomized block design (RAK) factorial design consisting of three replications with the first factor is the long of incubation (day 0,1,2 and 3), the second factor is the type of tested bacteria ( $E$. coli and $S$. aureus) and the third factor is the variation of the concentration (4.6 and 8\%). Then tested using Analysis of Varian (ANOVA), then continued with "Tukey" test with 95\% confidence interval. The most appropriate concentration in inhibiting the growth of tested bacteria is $8 \%$ of pedada fruit extract. The widest of clear zone is $18 \mathrm{~mm}$ on tofu treated with $8 \%$ pedada fruit extract (with S. aureus test bacteria).
\end{abstract}

Keywords: pedada fruit, tofu, inhibition zone, TPC

\begin{abstract}
ABSTRAK
Buah pedada adalah salah satu jenis tanaman mangrove mempunyai sifat antibakteri yang kuat yang belum banyak dimanfaatkan untuk pengawetan makanan. Tahu adalah makanan yang mudah rusak sehingga perlu diawetkan untuk memperpanjang umur simpannya. Tujuan penelitian ini adalah mengetahui pengaruh konsentrasi ekstrak buah pedada terhadap zona hambat, total bakteri uji, $\mathrm{pH}$ dan kadar air pada tahu selama penyimpanan suhu ruang, dan mengetahui konsentrasi ekstrak buah pedada yang tepat dalam menghambat pertumbuhan bakteri uji Escerichia coli dan Staphilococcus aureus pada tahu selama penyimpanan suhu ruang. Penelitian dilaksanakan dengan studi efektivitas antibakteri pada bakteri uji Escerichia coli dan Staphilococcus aureus dengan konsentrasi sari buah pedada 4\%, 6\% dan 8\%, kemudian dilakukan analisa mutu tahu selama penyimpanan dengan perendaman ekstrak buah pedada pada suhu ruang pada hari ke $0,1,2$ dan 3 penyimpanan. Penelitisn dilakukan dengan Rancangan Acak Kelompok (RAK) factorial dengan tiga kali ulangan dengan faktor pertama lama inkubasi (hari ke-0, 1, 2 dan 3) dan faktor kedua adalah jenis bakteri uji (E. coli dan $S$. aureus) dan factor ketiga adalah variasi konsentrasi ekstrak pedada (4,6 dan 8\%). Kemudian dilakukan uji statistic Analisys of Variance (Anova), kemudian dilanjutkan dengan uji "Tukey" dengan selang kepercayaan $95 \%$. Konsentrasi yang paling tepat dalam menghambat
\end{abstract}


pertumbuhan bakteri uji adalah buah pedada $8 \%$. Zona hambat terluas yaitu $18 \mathrm{~mm}$ pada tahu yang diberi perlakuan konsentrasi pedada $8 \%$ dengan bakteri uji $S$. aureus.

Kata Kunci : buah pedada, tahu, zona hambat, TPC

\section{PENDAHULUAN}

Buah pedada adalah salah satu jenis tanaman magrove berada di sepanjang pantai berlumpur dengan salinitas rendah. Buah pedada memiliki komponen steroid, triterpenoid, flavonoid, karboksil benzena dan memiliki sifat yang memiliki analgesik dan antiflamantori (Varghese et al., 2010). Ekstrak buah pedada secara tradisional digunakan sebagai antiseptik, mengobati keseleo, dan mencegah pendarahan (Minqing et al., 2009). Buah pedada sejak lama sudah diketahui mempunyai khasiat sebagai obat-obatan tradisional untuk mengobati beberapa penyakit. Buah pedada juga diketahui mempunyai aktivitas antibakteri yang cukup luas (Devi dkk., 1997).

Antibakteri adalah sifat dari suatu bahan yang menunjukkan efek penghambatan terhadap pertumbuhan bakteri karena memiliki 2 sifat bakterisidal dan bakeriostatik. Berdasarkan sifat tersebut buah pedada dapat dimanfaatkan sebagai pengawet alami produk pangan yang mudah mengalami kerusakan. Salah satu produk pangan yang mudah mengalami kerusakan adalah tahu.

Tahu adalah ekstrak protein kedelai yang telah digumpalkan dengan menggunakan bahan penggumpal protein seperti asam, garam kalsium, atau bahan penggumpal lainnya. Tahu termasuk bahan makanan yang tinggi kadar air dan protein,sehingga menjadi media terbaik untuk pertumbuhan bakteri pembusuk yang menyebabkan produk mempunyai daya awet rendah (Hamid, 2012). Bakteri yang menyebabkan kerusakan pada produk tahu adalah bakteri Escerichia coli dan Staphylococcus aureus.

Bakteri Escerichia coli dan Staphylococcus aureus merupakan bakteri patogen yang berbahaya bagi kesehatan. Escerichia coli adalah bakteri Gram negatif, yang menyebabkan diare pada manusia sedangkan Staphylococcus aureus adalah bakteri Gram positif yang mengkontaminasi produk pangan (Chotiah, 2006).

Berdasarkan uraian diatas dapat diketahui bahwa konsentrasi ekstrak buah pedada sebagai antibakteri memberikan pengaruh terhadap bakteri Escerichia coli dan Staphylococcus aureus dan mutu tahu yang disimpan pada suhu ruang. Pengaruh konsentrasi buah pedada pada penelitian ini diamati berdasarkan pola perubahan zona hambat, total bakteri uji, $\mathrm{pH}$ dan kadar air.

\section{METODE PENELITIAN}

Penelitian dilakukan melalui beberapa tahapan, (1). Pembuatan sari buah pedada (2).persiapan pembuatan tahu, (3) Kultivasi bakteri uji (E.coli, dan S.aureus) (4) pengukuran zona hambat (5) perhitungan total bakteri uji hasil kultivasi (6) $\mathrm{pH}$ dalam tahu dengan tambahan sari buah pedada, (7) analisa kadar air (8) Rancangan penelitian dan analisis data.

\section{Pembuatan sari Buah Pedada}

Buah pedada yang digunakan sebanyak $10 \mathrm{~kg}$ dengan karakteristik tidak busuk, berwarna hijau muda bulat. Pembuatan sari buah pedada diawali dengan ukuran sekitar $4 \mathrm{~cm}^{2}$, selanjutnya dihaluskan menggunakan blender. Buah pedada yang halus, disaring dengan kain saring. Filtrat yang diperoleh disentrifugasi dengan kecepatan $6500 \mathrm{rpm}$ suhu $4^{\circ} \mathrm{C}$ selama 15 menit, difilter menggunakan milipore 0,22 $\mu \mathrm{m}$. Filtrat yang diperoleh siap pergunakan.

\section{Persiapan pembuatan tahu kedelai}

Kedelai $10 \mathrm{~kg}$ yang diperoleh dipasar Sentap Ketapang dicuci, dijemur sampai 
butiran kacang pecah-pecah (4-7 hari), pemisahan biji kedelai dengan kulitnya, dicuci, direndam selama 12 jam, pencucian dan penirisan, kedelai yang lunak setelah direndam diblender sampai menjadi bubur, dilakukan perebusan sampai berbusa, disaring, ciran sari kedelai, penambahan bahan penggumpal tahu dan garam, pemisahan cairan whey dengan bubur tahu yang agak menggumpal, pencetakan, pendinginan, produk tahu jadi. Tahu ditempatkan dalam toples bundar, direndam dengan ekstrak buah pedada 4,6 dan $8 \%$ disimpan pada suhu ruang selama $0,1,2$ dan 3 hari.

\section{Uji kemampuan senyawa antibakteri dengan metode difusi agar}

Uji kemampuan senyawa antibakteri ekstrak buah pedada dengan beberapa konsentrasi (4,6 dan 8\%) dilakukan dengan metode difusi agar. Dalam uji difusi agar bakteri uji yang digunakan adalah E.coli, S.aureus dan L.monocytogenes. Langkah awal yang dilakukan adalah $15 \mathrm{ml}$ media Nutrium agar steril (hard medium) dituang dalam cawan petri steril, ditunggu hingga memadat dan $10 \mathrm{ml}$ soft medium (Nutrium broth yang diberi agar dengan konsentrasi $0,75 \%$ agar) diinokulasi dengan bakteri indikator yang telah diinkubasi 18 jam dan dihomogenisasi, kemudian dituang di atas hard medium. Media tersebut dibiarkan memadat dan dilubangi dengan cork borer berdiameter $6 \mathrm{~mm}$. Didalam lubang yang telah dibuat ditambahkan $100 \mu \mathrm{l}$ supernatan ekstrak buah pedada, dan disimpan dalam lemari es selama 12 jam, kemudian diinkubasi selama 24 jam pada $37^{\circ} \mathrm{C}$. Kemudian dilakukan pengukuran zona hambat yang terbentuk pada sekitar sumuran (Erdogrul and Erbilir, 2006).

\section{Perhitungan total bakteri uji pada tahu yang direndam dengan ekstrak Buah Pedada}

Pembuatan kurva pertumbuhan bakteri uji (E.coli, dan S.aureus) dilakukan untuk mengetahui jumlah sel tertinggi pada tiap variasi konsentrasi buah pedada pada tahu dengan waktu inkubasi hari 0,1,2, dan 3 . Kurva pertumbuhan bakteri uji dalam tahu dilakukan dengan metode Total Plate Count (TPC).

Penghitungan jumlah sel hidup pada susu pasteurisasi dilakukan dengan metode Total Plate Count (TPC) menggunakan Nutrient Agar, Metode TPC dilakukan dengan cara melakukan pengenceran berseri dari $10^{-1}$ sampai dengan $10^{-7}$. Sampel diambil sebanyak 0,1 g kemudian dimasukkan ke dalam $0,9 \mathrm{ml}$ pepton $\left(10^{-1}\right)$. Hal tersebut dilakukan sampai perngenceran $10^{-7}$. Biakan pada seri pengenceran $10^{-4}, 10^{-5}, 10^{-6}$ dan $10^{-7}$ diinokulasikan sebanyak $0,1 \mathrm{ml} \mathrm{ke}$ dalam cawan petri steril secara duplo dan dituangi dengan media Eosin Methilen Blue Agar (EMBA) untuk E.coli, Manitol Salt Agar (MSA) untuk S.aureus,. Selanjutnya dilakukan inkubasi pada suhu $37{ }^{\circ} \mathrm{C}$ dalam inkubator selama 24 jam. Hasil inkubasi berupa koloni yang muncul dalam media agar dengan karakteristik bakteri uji E.coli berwarna kehijauan, berkilau metalik dan bagian tengah biru kehitaman. Sedangkan untuk bakteri uji S.aureus dengan karakteristik warna kuning. Kemudian jumlah koloni pada cawan petri dihitung dan dimasukkan dalam rumus (Garbutt, 1997).

\section{Pengukuran pH}

Pengukuran $\mathrm{pH}$ pada susu tahu dilakukan untuk mengetahui pengaruh konsentrasi ekstrak buah pedada selama penyimpanan tahu. Pada pengukuran nilai $\mathrm{pH}$ yang terukur adalah konsentrasi ion hidrogen yang terdisosiasi (Frobisher et al., 1974) Pengukuran $\mathrm{pH}$ dilakukan pada waktu pengambilan sampel hari ke-0, 1, 2 dan 3 dengan menggunakan $\mathrm{pH}$ meter. Penggunaan $\mathrm{pH}$ meter diawali dengan membersihkan probe menggunakan akuades, digeser knob pada bagian atas dan dimasukkan $\mathrm{pH}$ meter ke dalam sampel sebanyak $10 \mathrm{ml}$ yang telah dihomogenkan menggunakan vortex. Angka yang tertera pada $\mathrm{pH}$ meter selanjutnya dibaca setelah stabil. Selanjutnya probe dibilas dengan akuades setiap selesai digunakan (Apriyantono dkk, 1989). 


\section{Analisa kadar air Metode AOAC (Sudarmadji dkk, 1984)}

Tahu yang telah dihaluskan ditimbang sebanyak 1-2 gram dalam cawan pengering yang telah diketahui beratnya. Keringkan dalam oven pada suhu $100-105^{\circ} \mathrm{C}$ selama 3 jam, didinginkan dalam eksikator dan ditimbang. Perlakuan diulang sampai tercapai berat konstan (selisih penimbangan berturut-turut kurang dari 0,2 mg). Pengurangan berat merupakan banyaknya air dalam bahan.

\section{HASIL DAN PEMBAHASAN}

\section{Perubahan pH tahu yang ditambah buah pedada dengan berbagai konsentrasi}

Nilai $\mathrm{pH}$ tahu sebelum penambahan buah pedada dengan konsentrasi $4 \%, 6 \%$ dan $8 \%$ adalah 4,36 sedangkan nilai $\mathrm{pH}$ buah pedada awal adalah 2, 82. Gambar 4.1 menunjukkan $\mathrm{pH}$ tahu yang diinokulasi dengan bakteri uji E.coli adalah 4,06 (hari ke-0) menjadi 4,70 (hari ke-3). Berdasarkan Gambar dibawah ini rerata nilai $\mathrm{pH}$ tertinggi tahu yang telah ditambahkan buah pedada diperoleh pada konsentrasi buah pedada $4 \%$ yaitu 3,10 (hari ke-0) menjadi 4,11 (hari ke3) dan nilai $\mathrm{pH}$ terendah pada konsentrasi buah pedada $8 \%$ yaitu 2,90 (hari ke-0) menjadi 3,72 (hari ke-3).

Gambar 1 menunjukkan hubungan antara lama penyimpanan dan $\mathrm{pH}$ yang menunjukkan perbedaan nyata (Sig. $<0,05)$. Hal tersebut terjadi karena selama penyimpanan akan terjadi peningkatan jumlah mikroorganisme yang terdapat pada tahu terutama bakteri E.coli akan mendegradasi senyawa yang terdapat pada tahu sebagai sumber nutrisi untuk tumbuh dan berkembangbiak. Semakin lama penyimpanan tahu pada suhu ruang maka akan meningkatkan jumlah mikroorganisme sehingga dapat menyebabkan degradasi protein yang menghasilkan $\mathrm{NH}_{3}$ yang bersifat basa sehingga $\mathrm{pH}$ pada tahu meningkat (Perangin-angin, 2013).

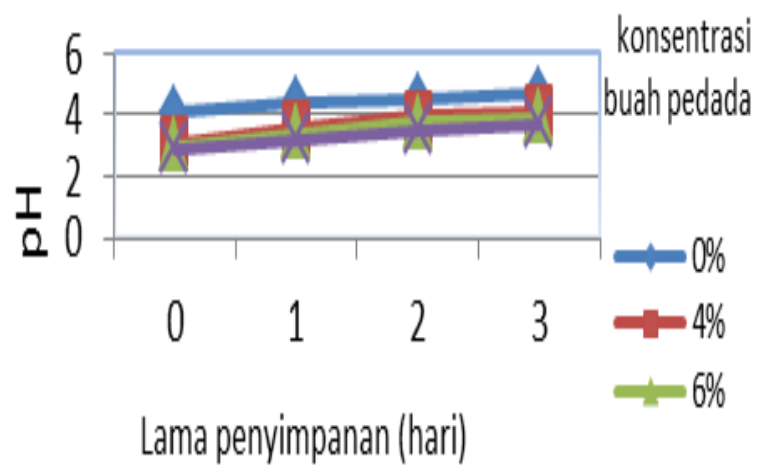

Gambar 1. Pola perubahan $\mathrm{pH}$ dalam tahu yang telah diinokulasi bakteri uji E.coli.

Variasi konsentrasi memberikan pengaruh terhadap nilai $\mathrm{pH}$, konsentrasi tertinggi diperoleh pada konsentrasi buah pedada $4 \%$ yaitu 3,10 (penyimpanan pada hari ke 0) dan 4,11 (penyimpanan pada hari ke-3). Nilai $\mathrm{pH}$ terendah diperoleh pada konsentrasi buah pedada $8 \%$ yaitu 2.90 (penyimpanan pada hari ke-0) dan 3,72 (penyimpanan pada hari ke-3). Hal tersebut dipengaruhi oleh senyawa antibakteri yang terdapat pada buah pedada, sehingga dengan semakin meningkatnya konsentrasi buah pedada maka semakin tinggi aktivitas senyawa antibakteri yang menghambat kerja bakteri uji. Senyawa aktif yang bersifat menghambat kerja bakteri uji adalah senyawa hidrokuinon (Arifuddin dkk, 2004). Nilai hasil uji lanjutan 'Tukey' dapat dilihat pada Tabel 1 .

Tabel 1 menunjukkan hasil uji lanjut "Tukey" pada nilai pH konsentrasi $0 \%$ buah pedada hari ke-0 lebih tinggi daripada konsentrasi 8\%. hari ke-4. Menurut Sofiani (2003), menyatakan bahwa besarnya aktivitas antibakteri dapat dipengaruhi konsentrasi zat antibakteri, spesies bakteri, jumlah dari bakteri target, dan $\mathrm{pH}$ lingkungan. 
Tabel 1. Uji Tukey perubahan $\mathrm{pH}$ dan konsentrasi buah pedada pada tahu

\begin{tabular}{cccc}
\hline Konsentrasi buah pedada & \multicolumn{3}{c}{ Rerata nilai $\mathrm{pH}$ tahu } \\
\hline $0 \%$ & $4,3750 \mathrm{a}$ & & \\
$4 \%$ & $3,6250 \mathrm{~b}$ & & \\
$6 \%$ & & $3,4463 \mathrm{c}$ & \\
$8 \%$ & & & $3,2663 \mathrm{~d}$
\end{tabular}

Keterangan: huruf yang berbeda di belakang nilai rata-rata pada baris dan kolom yang berbeda menunjukkan beda nyata berdasarkan uji "Tukey" pada tingkat signifikansi 95\%.

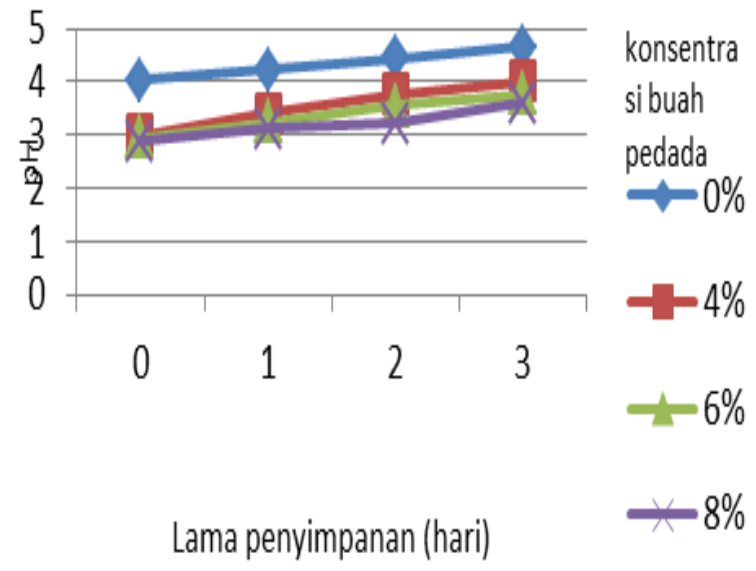

Gambar 2. Pola perubahan $\mathrm{pH}$ terhadap lama penyimpanan tahu yang telah diinokulasi bakteri uji S.aureus.

Gambar 2 menunjukkan bahwa rerata nilai $\mathrm{pH}$ tahu yang diinokulasi bakteri uji S.aureus adalah 4,04 (hari ke-0) menjadi 4,66 (hari ke-3). Nilai rerata $\mathrm{pH}$ tertinggi tahu setelah penambahan buah pedada dengan konsentrasi 4\% sebesar 3,00 (hari ke-0) menjadi 4,01 (hari ke-3) dan nilai rerata $\mathrm{pH}$ terendah diperoleh pada konsentrasi buah pedada $8 \%$ sebesar 2,88 (hari ke-0) menjadi3,61 (hari ke-3. Gambar diatas menunjukkan bahwa semakin lama waktu inkubasi dapat meningkatkan nilai $\mathrm{pH}$. Nilai hasil uji lanjutan 'Tukey' dapat dilihat pada Tabel 2.

Tabel 2 menunjukkan hasil uji lanjut "Tukey" pada nilai $\mathrm{pH}$ hari ke-0 lebih tinggi daripada hari ke-3. Hal tersebut didukung oleh peryataan Hayati, (2012) yang menyatakan bahwa asam organik mengalami ionisasi selama waktu inkubasi sehingga menyebabkan pelepasan ion $\mathrm{H}^{+}$yang mengakibatkan suasana media menjadi lebih asam.

\section{Kadar air}

Nilai kadar air tahu sebelum penambahan buah pedada dengan konsentrasi $(4 \% ; 6 \%$; dan $8 \%$ ) dan sebelum diinokulasi dengan bakteri uji adalah 23,37\% (bakteri S.aureus dan E.coli).

Tabel 2. Uji Tukey perubahan $\mathrm{pH}$ dan lama inkubasi pada tahu

\begin{tabular}{cccc}
\hline Lama inkubasi & \multicolumn{2}{c}{ Rerata nilai $\mathrm{pH}$ tahu } \\
\hline 0 hari & $4,3750 \mathrm{c}$ & & \\
1 hari & & $3,6250 \mathrm{~b}$ & \\
2 hari & & $3,4463 \mathrm{ab}$ & \\
3 hari & & & $3,2663 \mathrm{a}$ \\
\hline
\end{tabular}

Keterangan: huruf kecil yang berbeda di belakang nilai rata-rata pada baris dan kolom yang berbeda menunjukkan beda nyata berdasarkan uji "Tukey" pada tingkat signifikansi 95\%. 


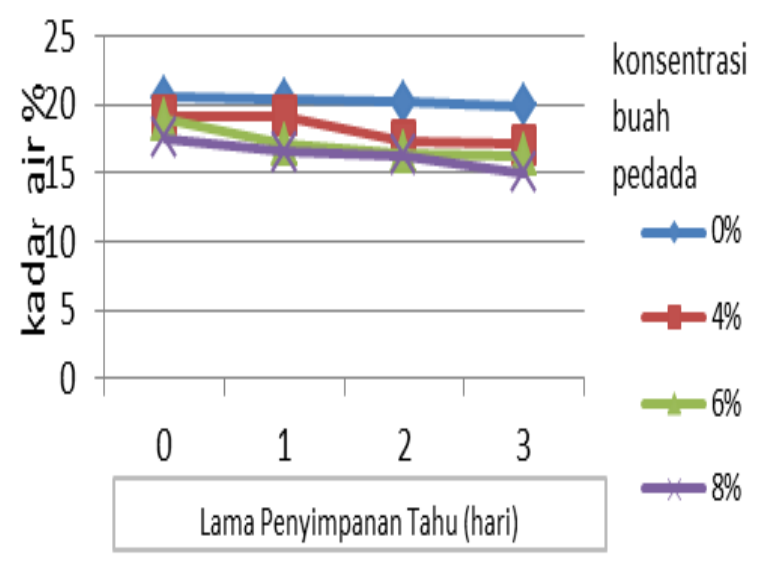

Gambar 3. Pola perubahan kadar air terhadap lama penyimpanan tahu yang telah diinokulasi bakteri uji E.coli

Gambar 3 menunjukkan rerata nilai kadar air dengan bakteri uji E.coli pada tahu adalah 20,57\% (hari ke-0) menjadi 19,52\% (hari ke-3). Rerata nilai kadar air tertinggi diperoleh pada tahu dengan penambahan konsentrasi buah pedada 4\% yaitu 19,22\% (hari ke-0) menjadi $17,15 \%$ (hari ke-3) dan rerata nilai kadar air terendah diperoleh pada tahu dengan penambahan konsentrasi buah pedada $8 \%$ yaitu $17,60 \%$ (hari ke-0) menjadi $15,04 \%$ (hari ke-3).

Selama penyimpanan kadar air tahu semakin menurun. Hal ini karena buah pedada yang ditambahkan mampu mengikat air pada protein tahu tersebut sehingga membentuk daya ikat protein dengan air semakin kuat, air bebas terikat menjadi air terikat, hal ini menyebabkan kadar air semakin menurun. Selama penyimpanan kandungan air didalam tahu mudah lepas diakibatkan kemampuan buah pedada mengikat air mengikat air berkurang.

Variasi konsentrasi memberikan pengaruh terhadap nilai kadar air, nilai tertinggi diperoleh pada konsentrasi buah pedada $4 \%$ yaitu 70,24 (penyimpanan pada hari ke 0) dan 64,71 (penyimpanan pada hari ke-3). Nilai kadar air terendah terendah diperoleh pada konsentrasi buah pedada $8 \%$ yaitu 70,06 (penyimpanan pada hari ke-0) dan 62,91 (penyimpanan pada hari ke-3) dengan bakteri uji E.coli. Hal tersebut dipengaruhi oleh senyawa antibakteri yang terdapat pada buah pedada, sehingga dengan semakin meningkatnya konsentrasi buah pedada maka semakin rendah aktivitas air pada bahan. Hal tersebut disebabkan sifat dari buah pedada yaitu bersifat mengikat air dikarenakan tinggi kandungan pati, sehingga pada saat perendaman pada tahu, buah pedada tersebut membentuk gel sehingga mengikat air pada bahan. Selain itu dikarenakan sifat senyawa antibakteri yang menghambat kerja bakteri uji. Senyawa aktif yang bersifat menghambat kerja bakteri uji adalah senyawa hidrokuinon (Arifuddin, 2004). Nilai hasil uji lanjutan 'Tukey' dapat dilihat pada Tabel 3 .

Tabel 3 menunjukkan hasil uji lanjut "Tukey" pada nilai kadar air konsentrasi $0 \%$ buah pedada lebih tinggi daripada konsentrasi $8 \%$. Hal tersebut dikarenakan kemampuan dari sifat menngikat air pada bahan pangan (Winarno, 2004).

Tabel 3. Uji Tukey perubahan kadar air dan lama inkubasi buah pedada pada tahu

\begin{tabular}{lccc}
\hline \multicolumn{1}{c}{ Lama inkubasi } & \multicolumn{2}{c}{ Rerata nilai kadar air $(\%)$} & \\
\hline 0 hari & $68,5228 \mathrm{a}$ & & \\
1 hari & $67,7300 \mathrm{~b}$ & \\
2 hari & & $67,0550 \mathrm{bc}$ & \\
3 hari & & & $66,5112 \mathrm{c}$
\end{tabular}

Keterangan: huruf kecil yang berbeda di belakang nilai rata-rata pada baris dan kolom yang berbeda menunjukkan beda nyata berdasarkan uji "Tukey" pada tingkat signifikansi $95 \%$. 


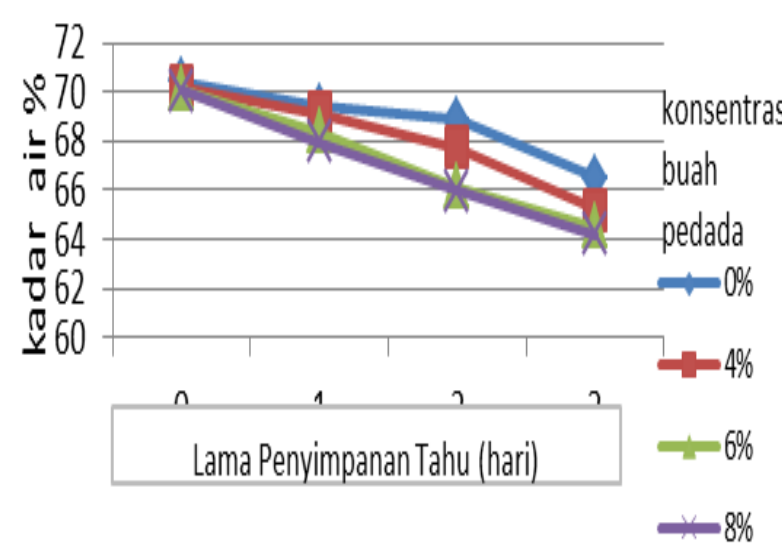

Gambar 4. Pola perubahan kadar air dalam tahu yang telah diinokulasi bakteri uji S.aureus

Gambar 4 menunjukkan pengaruh lama inkubasi terhadap kadar air tahu yang menunjukkan perbedaan nyata (Sig.<0,05). Hal tersebut karena selama penyimpanan kadar air tahu semakin menurun. Hal ini karena buah pedada yang ditambahkan mampu mengikat air pada protein tahu tersebut sehingga membentuk daya ikat protein dengan air semakin kuat, air bebas terikat menjadi air terikat, hal ini menyebabkan kadar air semakin menurun. Selama penyimpanan kandungan air didalam tahu mudah lepas diakibatkan kemampuan buah pedada mengikat air mengikat air berkurang.

\section{Total bakteri pada tahu dengan berbagai konsentrasi buah pedada}

Nilai total bakteri pada tahu sebelum penambahan buah pedada dengan 3 konsentrasi (4\%; 6\%; dan 8\%) dan sebelum diinokulasi dengan bakteri uji adalah 0,98 $\log \mathrm{cfu} / \mathrm{ml}$ (bakteri S.aureus).

Gambar 5 menunjukkan hubungan antara lama inkubasi dan total bakteri uji menunjukkan perbedaan nyata (Sig. $<0,05)$. Gambar tersebut menunjukkan rerata nilai total bakteri uji E.coli pada tahu adalah 4,15 $\log \mathrm{cfu} / \mathrm{g}$ (hari ke-0) menjadi 5,89 $\log \mathrm{cfu} / \mathrm{g}$ (hari ke-3). Rerata nilai total bakteri uji tertinggi diperoleh pada tahu dengan penambahan konsentrasi buah pedada $4 \%$ yaitu 3,62 log cfu/g (hari ke-0) menjadi 4,51 $\log \mathrm{cfu} / \mathrm{g}$ (hari ke-3) dan rerata nilai total bakteri uji terendah diperoleh pada tahu dengan penambahan konsentrasi buah pedada $8 \%$ yaitu 3,19 log cfu/g (hari ke-0) menjadi 3,61 log cfu/g (hari ke-3).

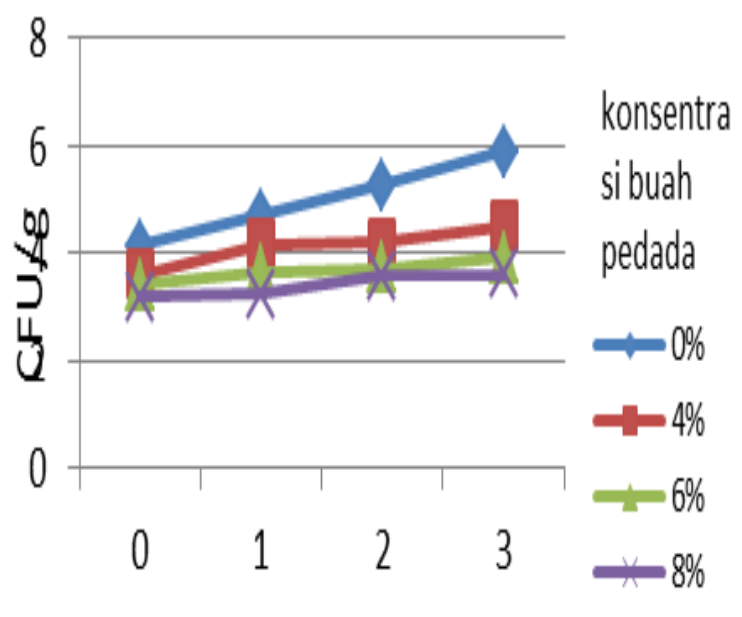

Gambar 5. Pola perubahan total bakteri uji dalam tahu yang telah diinokulasi bakteri uji E.coli.

Hal tersebut karena selama inkubasi senyawa bakteri uji memanfaatkan nutrisi dalam media untuk pertumbuhannya. Hasil uji lanjutan 'Tukey' menunjukkan adanya perbedaan nilai total bakteri uji selama inkubasi. Nilai total bakteri uji pada tahu hari ke-3 lebih tinggi daripada hari ke-0. Menurut Rahman (2010), menyatakan bahwa meningkatnya bakteri selama inkubasi karena komponen antimikrobia berikatan dengan komponen dalam makanan menyebabkan terjadi pemecahan dan pengurangan struktur kimia dari antimikrobia.

Tabel 4 menunjukkan hasil uji lanjut "Tukey" nilai total bakteri uji pada tahu dengan variasi konsentrasi buah pedada $4 \%$ lebih tinggi daripada konsentrasi buah pedada $8 \%$. Semakin meningkatnya konsentrasi maka sifat antibakterinya semakin tinggi. Hal tersebut sesuai dengan pernyataan Damayanti (2007), menyatakan bahwa antibakteri pada buah mengkudu masuk ke dalam dinding sel, menghambat sintesis peptidoglikan dinding sel, masuk ke dalam membran sitoplasma sel, kemudian mempengaruhi penguraian nutrien dalam roses metabolisme, menghambat, ke-mudian menyebabkan kematian sel. 
Tabel 4. Uji Tukey perubahan total bakteri uji dan variasi konsentrasi buah pedada pada tahu

\begin{tabular}{crrr}
\hline Konsentrasi buah pedada & \multicolumn{2}{c}{ Rerata nilai total bakteri E.coli } \\
\hline $0 \%$ & $4,8075 \mathrm{a}$ & & \\
$4 \%$ & $3,9475 \mathrm{~b}$ & \\
$6 \%$ & & $3,6013 \mathrm{bc}$ & \\
$8 \%$ & & $3,3688 \mathrm{c}$
\end{tabular}

Keterangan: huruf kecil yang berbeda di belakang nilai rata-rata pada baris dan kolom yang berbeda menunjukkan beda nyata berdasarkan uji "Tukey" pada tingkat signifikansi 95\%.

Menurut Schillinger et al. (1998) menyatakan konsentrasi nisin 10-500 IU/ml $(0,25-12,5 \mu \mathrm{g} / \mathrm{ml})$ menghasilkan sifat bakterisidal yang menghambat pertumbuhan $L$. monocytogenes dari level $10^{8} \mathrm{CFU} / \mathrm{ml}$ menjadi $10^{4} \mathrm{CFU} / \mathrm{ml}$ pada penyimpanan 24 jam.

Hasil uji antara lama inkubasi dan total bakteri uji menunjukkan perbedaan nyata (Sig.<0,05). Hal tersebut karena selama inkubasi senyawa bakteri uji memanfaatkan nutrisi dalam media untuk pertumbuhannya.

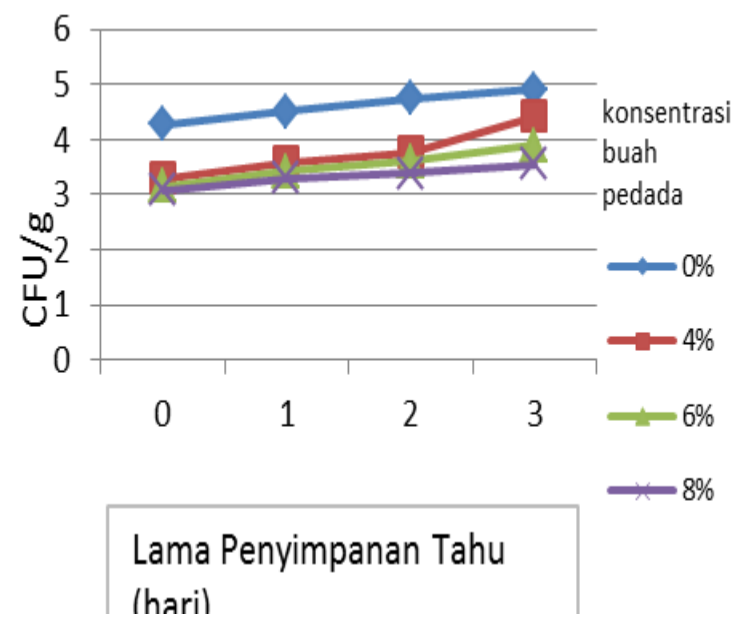

Gambar 6. Pola perubahan total bakteri uji dalam tahu yang telah diinokulasi bakteri uji S.aureus.

Gambar 6 menunjukkan hubungan antara jenis bakteri uji dan total bakteri uji menunjukkan perbedaan nyata (Sig.<0,05). Hal tersebut karena sensitifitas bakteri terhadap antibakteri dan kemampuan pertumbuhan dari tiap bakteri uji berbeda.
Hasil uji lanjutan 'Tukey', nilai total bakteri E.coli lebih tinggi daripada S.aureus. Menurut Sokatch (1969), menyatakan bahwa $E$. coli merupakan bakteri Gram negatif dengan komposisi terbesar penyusun dinding sel adalah lemak sehingga sulit ditembus oleh senyawa antimikrobia. Perbedaan struktur dinding sel menentukan penetrasi, ikatan dan aktivitas senyawa antibakteri.

Hasil uji lanjutan 'Tukey' (Tabel 5) menunjukkan adanya perbedaan nilai total bakteri uji selama inkubasi. Nilai total bakteri uji pada tahu dengan penyimpanan hari ke-4 lebih tinggi daripada hari ke-0.

Bakteri Escherichia coli memiliki lapisan dinding sel yang dilapisi oleh membran luar yang terdapat protein, fosfolipid, dan lipopolisakarida dan periplasmik (Ibrahim, 2007). Pada bakteri $S$. aureus yang memiliki lapisan dinding sel yang terdiri dari lapisan peptidoglikan, asam teikoat, dan sedikit lipid (Ibrahim, 2017) yang dapat dihambat dengan mudah oleh ektrak herba krokot.

Lapisan bakteri gram positip berstruktur peptidoglikan, sedikit lipid dan asam asam teikoat. Asam teikoat merupakan polimer yang larut dalam air dan bersifat polar. Senyawa flavonoid merukan senyawa yang bersifat polar sehingga mudah menembus lapisan peptidoglikan yang bersifat polar daripada lapisan lipid yang bersifat non polar seperti yang ada di E. coli (Dewi, 2010). 
Tabel 5. Uji Tukey perubahan total bakteri uji dan lama inkubasi buah pedada pada tahu

\begin{tabular}{ccrr}
\hline Lama inkubasi & \multicolumn{2}{c}{ Rerata total bakteri uji } \\
\hline 0 hari & $4,8075 \mathrm{a}$ & & \\
1 hari & $3,9475 \mathrm{~b}$ & \\
2 hari & & $3,6013 \mathrm{bc}$ & \\
3 hari & & $3,3688 \mathrm{c}$
\end{tabular}

Keterangan: huruf kecil yang berbeda di belakang nilai rata-rata pada baris dan kolom yang berbeda menunjukkan beda nyata berdasarkan uji "Tukey" pada tingkat signifikansi 95\%.

\section{Perubahan zona hambat pada buah pedada}

Nilai zona hambat pada tahu yang diinokulasi dengan bakteri uji dan penambahan buah pedada dengan berbagai konsentrasi buah pedada diperoleh selama inkubasi hari ke-0 hingga hari ke-3. Besarnya nilai zona hambat pada tahu dapat dilihat pada Gambar 7 berikut.

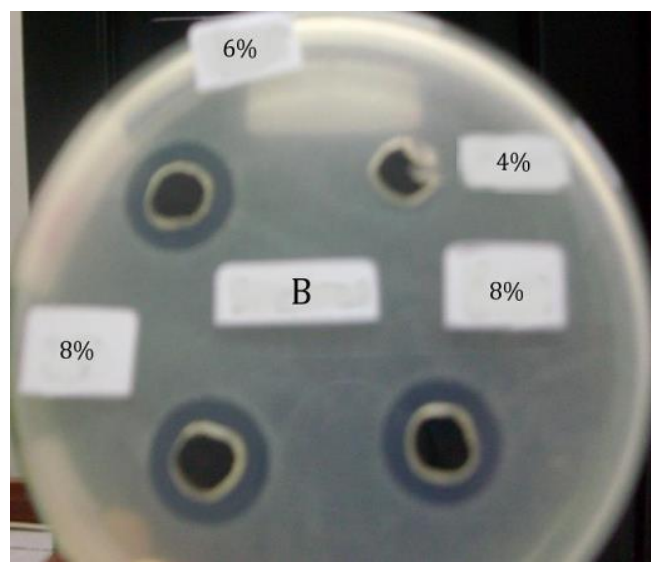

Keterangan: $4 \%=$ konsentrasi buah pedada $4 \%$

$6 \%=$ konsentrasi buah pedada $6 \%$

$8 \%=$ konsentrasi buah pedada $8 \%$

Gambar 7. Pembentukan zona hambat buah pedada pada tahu yang diinokulasi dengan bakteri uji E.coli (A), S. aureus (B).

Gambar 7 menunjukkan nilai zona hambat buah pedada pada konsentrasi $8 \%$ dengan bakteri uji S.aureus lebih tinggi daripada zona hambat yang dihasilkan pada konsentrasi buah pedada $4 \%$ dengan bakteri uji E.coli.

Hasil uji Anova antara lama inkubasi dan zona hambat menunjukkan perbedaan nyata (Sig. $<0,05)$. Hasil uji lanjutan 'Tukey' zona hambat pada tahu dengan perlakuan lama inkubasi dapat dilihat dalam Tabel 6 .

Tabel 6 menunjukkan nilai zona hambat pedada dari hasil uji lanjut "Tukey" diperoleh nilai zona hambat yang berbeda pada tiap inkubasi. Nilai zona hambat pedada tertinggi diperoleh pada inkubasi tahu hari ke-0 dan nilai zona hambat buah pedada terendah pada inkubasi tahu hari ke3. Menurut Wolk dan Wheeler (1984) senyawa fenol merupakan senyawa antibakteri yang terdapat dalam buah-buahan. Waktu inkubasi menyebabkan penurunan kadar senyawa fenol yang terdapat pada buah pedada hal ini sesuai dengan penelitian Mariati (2000), menyatakan bahwa perlakuan inkubasi dapat menurunkan senyawa fenol pada buah mengkudu. Faktor-faktor yang menyebabkan penurunan senyawa fenol antara lain; adanya reaksi oksidasi selama fermentasi, terbentuknya hidrogen peroksida selama fermentasi dan kemungkinan tumbuhnya kelompok Bacillus $s p$. yaitu Bacillus coagulans yang dapat mendegradasi fenol (Mariati, 2000).

Tabel 6. Uji Tukey perubahan zona hambat buah pedada dan lama inkubasi pada tahu 


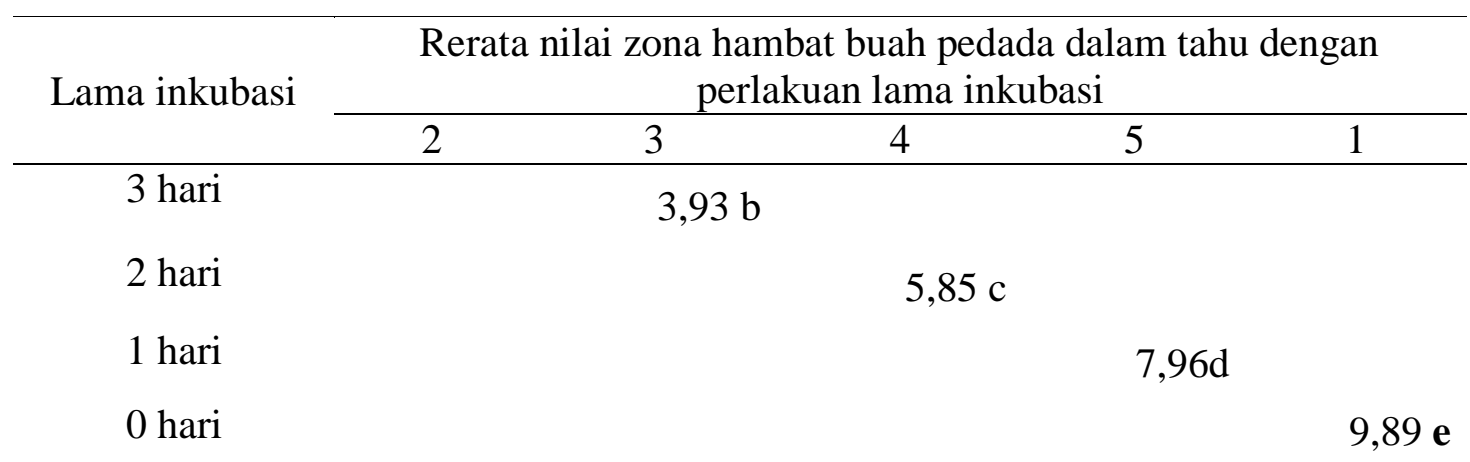

Keterangan: huruf kecil yang berbeda di belakang nilai rata-rata pada baris dan kolom yang berbeda menunjukkan beda nyata berdasarkan uji "Tukey" pada tingkat signifikansi 95\%.

Hasil uji Anova, antara jenis bakteri dan zona hambat menunjukkan perbedaan nyata (Sig.<0,05). Hasil uji lanjutan 'Tukey' (Tabel 4.7), menunjukkan bahwa nilai zona menunjukkan bahwa nilai zona hambat pedada dalam tahu yang diinokulasi bakteri uji S.aureus lebih tinggi daripada tahu yang diinokulasi bakteri uji E.coli. Menurut Fardiaz dalam Ardiansyah (2001), menyatakan bahwa S.aureus termasuk Gram positif mempunyai kecenderungan lebih sensitif dibandingkan dengan bakteri Gram negatif disebabkan karena perbedaan struktur dinding selnya. Susunan dinding sel bakteri Gram positif umumnya lebih sederhana dibandingkan dengan bakteri Gram negatif, sehingga lebih mudah ditembus oleh senyawa antimikroba.

Tabel 7. Uji Tukey perubahan zona hambat buah pedada dan variasi konsentrasi pedada pada tahu

\begin{tabular}{lcc}
\hline \multirow{2}{*}{$\begin{array}{c}\text { Jenis bakteri } \\
\text { uji }\end{array}$} & \multicolumn{2}{c}{$\begin{array}{c}\text { Rerata zona hambat } \\
\text { pedada dengan perlakuan } \\
\text { 2 jenis bakteri uji }\end{array}$} \\
\cline { 2 - 2 } $\begin{array}{l}\text { E.coli } \\
\text { S.aureus }\end{array}$ & $3,6444 \mathrm{a}$ & 3 \\
\hline
\end{tabular}

Keterangan: huruf kecil yang berbeda di belakang nilai rata-rata pada baris dan kolom yang berbeda menunjukkan beda nyata berdasarkan uji "Tukey" pada tingkat signifikansi 95\%

Hasil uji Anova antara variasi konsentrasi pedada dan zona hambat menunjukkan perbedaan nyata (Sig.<0,05).
Hasil uji lanjutan 'Tukey' (Tabel 7), menunjukkan bahwa konsentrasi pedada $8 \%$ dalam tahu menghasilkan zona hambat lebih besar yaitu $18 \mathrm{~mm}$ daripada konsentrasi pedada $4 \%$ yang ditambahkan dalam tahu. Hal tersebut sesuai dengan penelitian Efri (2004) yang menyatakan bahwa konsentrasi mengkudu $8-10 \%$ dapat menekan pertumbuhan bakteri uji E.coli dan S.aureus sehingga menghasilkan zona hambat yang luas $(18-20 \mathrm{~mm})$.

Tabel 8 Uji Tukey perubahan zona hambat pedada dan variasi konsentrasi pedada pada tahu

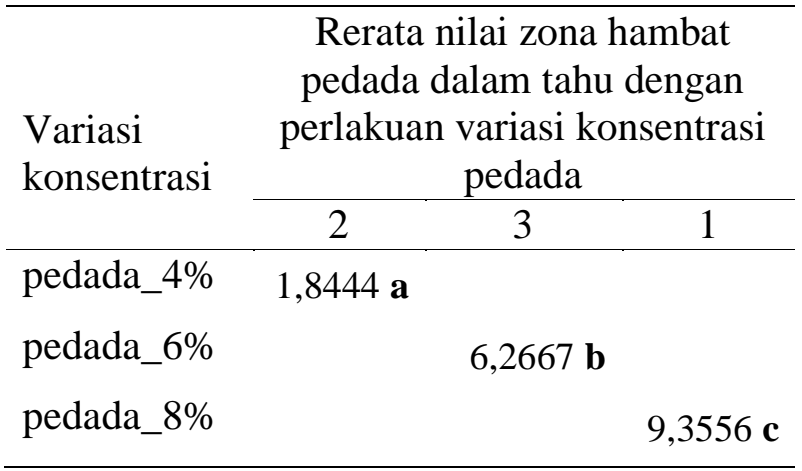

Keterangan: huruf kecil yang berbeda di belakang nilai rata-rata pada baris dan kolom yang berbeda menunjukkan beda nyata berdasarkan uji "Tukey" pada tingkat signifikansi 95\%

Hasil uji Anova menunjukkan perbedaan yang nyata pada perubahan zona hambat pedada pada variasi konsentrasi pedada pada tahu dengan selang kepercayaan 95\%, menunjukkan bahwa 
pada konsentrasi $8 \%$ dalam tahu menghasilkan zona hambat terbesar.

\section{KESIMPULAN}

1. Konsentrasi yang paling tepat dalam menghambat pertumbuhan bakteri uji adalah buah pedada $8 \%$. Konsentrasi tersebut mampu menurunkan jumlah bakteri E.coli yang diinokulasi dalam susu 4, $32 \log$ (cfu/ml) menjadi 3,19 $\log (\mathrm{cfu} / \mathrm{ml})$ (hari ke-0), S.aureus yang diinokulasi 4,26 log (cfu/ml) menjadi 3,09 log (cfu/ml) (hari ke-0).

2. Parameter perubahan $\mathrm{pH}$ pada setiap tahap penelitian yaitu 3,10 (hari ke-0) menjadi 4,11 (hari ke-3) dengan konsentrasi buah pedada $4 \%$ serta bakteri uji E.coli. sedangkan nilai $\mathrm{pH}$ untuk bakteri uji $S$. Aureus adalah 3,00 (hari ke-0) dan 4,01 (hari ke-3). Nilai kadar air terendah pada konsentrasi buah pedada $8 \%$ yaitu 7,05 (hari ke-0) dan 64,17 (hari ke-3) dengan bakteri uji S.aureus.

3. Zona hambat terluas yaitu $18 \mathrm{~mm}$ pada tahu diperoleh pada kombinasi variasi konsentrasi pedada $8 \%$ bakteri uji S.aureus.

\section{DAFTAR PUSTAKA}

Ahmed, R ., S. J. Moushumi, H. Ahmed, M. Ali, W. M. Haq, R. Jahan, M. Rahmatullah. (2010). Serum glu-cose and lipid profiles in rats following administration of Sonneratia Caseolaris (L.) Engl. (Sonneratiaceae) leaf powder in diet. Advances in Natural and Applied Sciences, 4(2): 171-173.

Apriyantono, (1989). Petunjuk Laboratorium Analisis Pangan. Pusbangtepa IPB. Bogor.

Arifuddin, Sukenda, D. Dana. (2004). Manfaat bahan aktif hidrokuinon dari buah Sonneratia caseolaris untuk mengendalikan infeksi buatan Vibrio harveyi pada udang windu, Penaeus monodon FAB. Jurnal Akuakultur Indonesia, 3(1):29-35.

Chotiah, S. (2006). Beberapa Bakteri Patogen Yang Mungkin Dapat Ditemukan Pada Susu Sapi dan Pencegahannya. Balai Besar Penelitian Veteriner. Bogor.

Damayanti, L. (2007). Pengaruh Teat Spray dengan Menggunakan Jus Buah Mengkudu dalam Berbagai Konsentrasi terhadap Hasil Uji CMT dan TPC pada Sapi Perah. Skripsi Fakultas Peternakan Universitas Brawijaya. Malang

Dewi, F. K. (2010). Aktivitas Anti Bakteri Ekstrak Etanol Buah Mengkudu Terhadap Bakteri Pembusuk Daging Segar. Skripsi. Fakultas MIPA Universitas Sebelas Maret Surakarta.

Duke, J.A. (1983). Sonneratia caseolaris (L.) Engl. Handbook of Energy Crops. Unpublished.http://www.hort.purdue.e du/newcrop/duke_energy/Sonneratia_ caseolaris.html. diakses tanggal 21 April 2011.

Erdogrul, O. and Erbilir, F. (2006). Isolation and Characterization of Lactobacillus bulgaricus and Lactobacillus casei from various Food. Turk. J. Biol, 30:39-44.

Garbutt, J. H. (1997). Essentials of Food Microbiology. Hodder Arnold Publication, London.

Ghalib, R. M., R.Hashim, O. Sulaiman, M. F.B. Awaludin, S.H. Mehdi, F. Kawamura. (2011). Fingerprint chematoxonomic GC-TOFMS pro-file of wood and bark of mangrove tree Sonneratia caseolaris (L.) Eng. Journal of Saudi Chemical Society. 15(3): 229- 237.

Hamid, M. (2012). Kandungan dan Manfaat Tahu. Penebar Swadaya, Jakarta.

Hayati, A. (2012). Pengaruh Perendaman Asam Organik Terhadap Kelarutan Mineral Kerang Darah (Anandara 
granosa). Skripsi. Fakultas Perikanan dan Ilmu Kelautan Institut Pertanian, Bogor.

Ibrahim, M. (2007). Mikrobiologi: Prinsip dan Aplikasi. Unesa University Press, Surabaya

Jariyah, (2013). Efek Hipoglikemik Tepung Pedada (Sonneratia caseolaris (L.) ENG.) Pada Tikus Wistar Yang Diinduksi Aloksan. Jurusan Teknologi Hasil Pertanian. Universitas Pembangunan Nasional Veteran. Jawa Timur.

Manulu, R. D. E. (2011). Kadar Beberapa Vitamin Pada Buah Pedada (Sonneratia caseolaris) dan hasil olahannya Skripsi. Departemen Teknologi Hasil Perairan. FPIK-IPB.

Minqing, T. D. Haofu, LI Xiaoming, Wang Bingui. (2009). Chemical constituents of marine medical mangrove plant Sonneratia caseolaris. Chinese Journal of Oceanology and Limnology, 27 (2) : 288-296.

Noor, Y. R., M. Khazali, Suryadiputra. (2006). Panduan Pengenalan Mangrove di Indonesia. Bogor. PHKA/WI-IP.

Perangin-angin, B. H. (2013). Pengaruh Derajat Keasaman dan Konsentrasi Ragi terhadap Mutu Minuman. Agricultural Prod. Technology 5(2).

Purnobasuki, H. (2004). Potensi Mangrove sebagai tanaman obat. Jurnal Biota. IX (2) :125-126.

Qi-Jie, Z., Wang Bo Sun, Wang Yong-Jun, Li Ming-Guang. (2003). Ecologigal Assessment on the Introduction Sonneratia caseolaris and S.apetala at the Mangrove Forest of Shenzhen Bay, China. Acta Botanica Sinica. 45(5):544-551.
Rahman, A. (2010). Uji Potensi Antimikroba Ekstrak Bunga Turi Merah. Skripsi. Fakultas Kedokteran Universitas Brawijaya, Malang.

Rahmatullah, M., Md. N. K. Azam, S. Pramanik, Sania, S. Rahman, R. Jahan. (2012). Antihyperglycemic activity evaluation of rhizomes of Curcuma zedoaria (Christm.) roscoe and fruits of Sonneratia caseolaris (L.) Engl. International Journal of PharmTech Research, 4(1):125-129.

Schillinger, U., H.S. Chung, K. Keppler. Holzapfel, W. H. (1998). Use of bacteriocinogenic lactic acid bakteria to inhibit spontaneous nisin-resistant mutants of Listeria Monocytogenes Scott A. Journal of Applied Microbiology 85 (4) :657-663.

Sofiani, Y. S. (2003). Isolasi, Pemurnian, dan Uji Aktivitas Antibakteri Senyawa Sinensetin dari Ekstrak Daun Kunis Kucing (Orthosiphonis aristatus). Skripsi Fakultas MIPA. Institut Pertanian Bogor, Bogor.

Sokatch, J. R. (1969). Bacterial Physiology and Metabolism. Academic Press: London

Sudarminto, S. Y. dan Tri Susanto. (2001). Pengujian Fisik Pangan. Penerbit Unesa University Press : Surabaya

Varghese, J. K., N. Belzik, A. R. Nisha, S. Resmi, K. S. Silvipriya. (2010). Pharmacognotical and phyto-chemical studies of a mangrove (Sonneratia caseolaris) from Kochi of Kerala State in India. Journal Pharmacy research, 3(11): 2625-2627.

Winarno, F. G. (2004). Kimia Pangan dan Gizi. Gramedia Pustaka Utama, Jakarta. 